\title{
Stilbenoids from Leguminosae and their Bioactivities
}

\author{
Xinyu Lei, ${ }^{a, b}$ Qinru Zhou, ${ }^{a, b}$ Wenju Li, ${ }^{b}$ Guifang Qin, ${ }^{a, b}$ Xiangchun Shen, ${ }^{*, a, b}$ and Nenling Zhang ${ }^{*, a, b}$ \\ ${ }^{a}$ School of Pharmacy, Guizhou Medical University/Engineering Center of Efficient Utilization of \\ Natural Medicinal Resources, Guiyang, Guizhou 550025, China \\ ${ }^{b}$ High Educational Key Laboratory of Guizhou Province for Natural Medicinal Pharmacology and \\ Drug Druggability/Key Laboratory of Optimal Utilization of Natural Medicinal Resources,
} Guiyang, Guizhou 550025, China

Email: shenxiangchun@126.com (X.S.), nenlingzhang@foxmail.com (N. Z.)

\begin{abstract}
Stilbenoids, usually found in Leguminosae, are a class of compounds with the skeleton of stilbene or their polymers, existing mostly in the xylem of plants. Till now, one hundred and seventy-six stilbenoids have been isolated from plants of Leguminosae. Herein, stilbene compounds and their derivatives in Leguminosae and their biological activities including anti-neoplastic, anti-bacterial, anti-inflammation are reviewed.
\end{abstract}

Keywords Leguminosae, stilbene, stilbenoids, bioactivities

\section{Introduction}

Leguminosae family is one of the largest families in the plant kingdom, which contains thousands of species. There are three subfamilies of the Leguminosae family, which are Fabaceae (Papilionoideae), Caesalpiniaceace and Mimosaceae. ${ }^{[1]}$ The latest research shows that, 33 families, 183 genera and 1859 species (including naturalized and cultivated species) of Leguminosae are distributed in China. The plants in this family can be trees, shrubs, subshrubs or herbs, erect or climbing, often with nitrogen-fixing nodules. ${ }^{[2]}$ By 2014, more than 70 species of plants in at least 20 families and 30 genera have been reported to have stilbenoids. ${ }^{[3,4]}$ Stilbenoids can be categorized into diphenylethyl, phenanthrene, stilbene monomers, and polymers. In addition to the antibacterial activity found at an early age, some stilbenes have also been found to have anti-tumor, insecticidal, antiviral, anti-inflammatory, anti-senile dementia, coronary vasodilation, antihypertensive, anti-allergic, hepatocytes protecting and blood lipid reducing activities. ${ }^{[3]}$ In this minireview, we summarize the stilbenes from Leguminosae and their bioactivities.

\section{Stilbenes isolated from Leguminosae}

Up to now, stilbenes have been found in many genera of Leguminosae, such as Cajanus, Caragana, Castanopsis, Deguelia, Lysidice, Arachis, and so on. Li et al. ${ }^{[5]}$ isolated a pair of new enantiomers stilbene dimer $(+)$-and (-)-Cajanusine $[(+)-1$ and $(-)-1]$ with unique coupling patterns from the leaves of pigeon pea (Cajanus Cajan) (1-2). Two stilbene compounds, longistylin $A$ and $C(3-4)$ were isolated from the leaves of pigeon pea by Duker-Eshun et al. ${ }^{[6]}$ According to the investigation and research of Tao and others, there were 44 stilbene compounds in Leguminosae from 1995 to $2008,{ }^{[7]}$ cicerfuran $(5),{ }^{[8]}$ pawhuskins $\mathrm{A}-\mathrm{C}(6-8),{ }^{[9]} 5$-methoxy- $E$ resveratrol-3-O-rutinoside (9), ${ }^{[10]} 2$ '-O-demthylbidwillol $B$, addisofurans $\mathrm{A}-\mathrm{B}(\mathbf{1 0}-\mathbf{1 2}),{ }^{[11]}$ burttionl $\mathrm{D}(\mathbf{1 3}),{ }^{[12]}(E)-3,4^{\prime}$-dimethoxy-5-rutinsoyl-stilbene (14), ${ }^{[13]} 3,5$-dimethoxy-4'-O( $\beta$-rhamnopyranosyl-( $1 \rightarrow 6)$ - $\beta$-glucopyranoside) stilbene $(15),{ }^{[14]}$ lespedezavirgatol (16), ${ }^{[15]}$ chiricanines A-E (17-21), ${ }^{[16]}$ 4-hydroxy-5'-methoxy-6",6"-dimethylpyran[2",3",3',4"]stilbene (22), 3,5-dimethoxy-4-hydroxy-6",6"-dimethylpyran[2",3",3",4"]- stilbene (23),3,4,5-trimenthoxy-6",6"-dimethylpyran[2",3",3',4"]stilbene (24), ${ }^{[17]}$ macheariols $A-B(25-26),{ }^{[18]}$ trans-4-[2(3,5-dimethoxyphenyl)ethenyl]-1,2-bezenediol (27), ${ }^{[19]}$ cararosinol A (28), ${ }^{[20]}(+)$-isoampelopsin $F(29)$ and (-)-isoampelopsin $F$ (30), caraphenols A-C $(\mathbf{3 1 - 3 3}),{ }^{[21]}$ carasinols A-C (3436), ${ }^{[22]}$ caragaphenol A (37), ${ }^{[23]}$ tibeticanol (38), ${ }^{[24]}$ T-epi,8'epi,11-de-O-methyl-5'-methoxygnetifolin $F(39),{ }^{[25]}$ leachianols C-G $(40-44),{ }^{[26]}$ davidiols A-C (45-47), ${ }^{[27]}$ stenophyllol B (48). ${ }^{[28]}$ In recent years, scholars have done a lot of research on the chemical constituents of pigeon pea. Cai et al. ${ }^{[29]}$ isolated a new natural halogen-containing stilbene derivative from the leaves of Cajanus cajan (L.) Millsp, and named cajanstilbene $\mathrm{H}$ (49). Zhang et al. ${ }^{[30,31]}$ reported the isolation, structural elucidation, and cytotoxicities of cajanstilbenoid $A$, cajanstilbenoid $B$, cajanotone, cajanamide $A(50-53)$, and other four known stilbenes $\left(\mathbf{5 4 - 5 7 )}\right.$. Wu et al. ${ }^{[32]}$ carried out phytochemical research on the plant Cajanus cajan and resulted in the isolation of four new stilbenes, determined as cajanusins $A-D$ (58-61). Stilbene compounds are also the characteristic components of the genus Caragana. Jeong et al. ${ }^{[33]}$ isolated a new oligostilbene from the roots of Caragana sinica. The structure of caragasinin $C(62)$ was established on the basis of spectroscopic techniques, including HRESIMS, 1D and 2DNMR. Lan et al. ${ }^{[34]}$ summarized 33 stilbene compounds, i.e., Caragan, resveratrol $(63),{ }^{[35]}$ piceatannol $(64),{ }^{[24]}$ isorhpontigenin (65), ${ }^{[24]}$ pinosylvin (66), ${ }^{[36]}$ 2-(4-hydroxyphenytacetyl)-4methoxy-6-hydroxy benzoic acid (67), ${ }^{[35]}$ cassigarol E (68), cassigarol G (69), maackin (70), cararosinol C-D (71-72), cis-scirpusin A (73), scirpusin A-B (74-75), ${ }^{[24]}$ pallidol $(76),{ }^{[35]}$ kompasinol $A(77),{ }^{[24]}$ caragasinin $A(78),{ }^{[37]}$ caragasinin $B$, miyabenol $C$, leachianol $C$, kobophenol $A$, carasiphenol D $(79-83){ }^{[38]}(+)$ - $\alpha$-viniferin, carasiphenol $B$, and carasiphenol $C$ $(\mathbf{8 4}-86),{ }^{[39]}(+)$-stenophyllol $B$, carasinols $A-C$, carasinol D, carasinasurone, carasiphenol A $(87-93),{ }^{[35]}$ cararosinol B $(94),{ }^{[40]}$ cararosin (95). ${ }^{[41]}$ Ngoupayo et al. ${ }^{[42]}$ reported the isolation and structure elucidation of compounds from the stems of Erythrophleum suaveolens, including a new stilbenoid, suaveolensone A (96). Nguyen et al. ${ }^{[43]}$ isolated a new stilbenoid (97) from the soluble extract of EtOAc from the root bark of Erythrina addisoniae. Currently, Marques reported that 18 stilbenes (98-115) and their derivatives had been isolated 
from the Deguelia genus. ${ }^{[44-51]}$ New prenylated stilbene derivatives, 3-hydroxy-4-prenyl-5-methoxy-stilbene acid (116) and 5,4'-dihydroxy-3methoxy-2-prenyl-stilbene (117) had been isolated from methanol extract of Cajanus cajan (L.) Millsp. ${ }^{[52]}$ At present, a number of resveratrol derivatives have been isolated and extracted from peanuts, trans-resvratrol, cis-resveratrol, trans-piced, cis-piceid, arachidin I, arachidin II, arachidin III (118-124), ${ }^{[53]}$ cudrastilbene, 3,5,3'-trihydroxy-4'methoxy-5'-isopentenylstlbene, arahypin B, arahypin-13, arahypin-14, arahypin-15, arahypin-6, arahypin-7, arahypin-11, arahypin-12 (125-134). ${ }^{[54]}$ Seven stilbene compounds (135141) were isolated from Maackia hupehensis (135-141). ${ }^{[55]}$ Compound 142 was isolated from C. chinensis. ${ }^{[56]}$ Four stilbene compounds (143-146) have been isolated from the genus Amorpha of Leguminosae. ${ }^{[57-59]}$ Stilbene is one of the most abundant components in the genus Euphorbia, especially in the Lysidice rhodostegia Hance of short calyx. ${ }^{[60]} \mathrm{Gao}^{[61]}$ isolated the compounds 147-149 from the Lysidice rhodostegia Hance. Gao et al. ${ }^{[62]}$ isolated the compounds 157 and 164 from $n$-butanol fraction of the Lysidice rhodostegia Hance. Hu ${ }^{[63]}$ isolated eight stilbene compounds 150-156, 163 from the Lysidice rhodostegia Hance of by high performance liquid chromatography-electrospray tandem mass spectrometry. Compounds 158-167 were isolated from the Lysidice rhodostegia Hance by Hu et al. ${ }^{[64,65]} \mathrm{Qu}^{[66]}$ obtained compound 168 from Lysidice brevicalyx. Compounds 170-176 were also isolated from the Lysidice rhodostegia Hance. ${ }^{[67-69]}$

All structures of stilbenes from Leguminosae are shown in Figure 1.

\section{Bioactivities of stilbenes from Leguminosae}

In addition to the early-reported antibacterial activity, some stilbene compounds have been found to also have antineoplastic activity, anti-insect effect, anti-inflammatory and analgesic effect, antimalarial, hypoglycemic, antioxidant, estrogenic and other physiological activities.

\section{Antineoplastic activity}

(+)-Cajanusine and (-)-cajanusine (1-2) exhibited inhibitory activities on the growth of human hepatocellular carcinoma cells. ${ }^{[5]}$ Cajanstilbene (49) showed a moderate inhibitory effect on cell proliferation, with $\mathrm{IC}_{50}$ values of 21.42-25.85 $\mathrm{\mu mol} \cdot \mathrm{L}^{-1},{ }^{[29]}$ Cajanstilbenoid A (50) showed strong cytotoxicity against HepG2, MCF-7, and A549 cells ( IC $_{50}$ values: 2.14-2.56 $\mu \mathrm{M})$. However, Cajanstilbenoid B (51) showed strong toxicity only against HepG2 $\left(\mathrm{IC}_{50}\right.$ value: $\left.5.99 \mu \mathrm{M}\right)$ and $\mathrm{A} 549$ cells $\left(\mathrm{IC}_{50}\right.$ value: $\left.6.18 \mu \mathrm{M}\right){ }^{[31]}$ Cajanotone (52) and Cajanstilbene acid (54) showed strong cytotoxicity against A549 cells (with $\mathrm{IC}_{50}$ values of 5.9 and $4.4 \mu \mathrm{M}$, respectively), but moderate cytotoxicity against HepG2 and MCF-7 cell lines (with $\mathrm{IC}_{50}$ values from 12.2 to $17.9 \mu \mathrm{M}$ ), pinosylvin monomethyl ether (55) showed strong cytotoxicity against MCF-7 (with an $\mathrm{IC}_{50}$ value of $8.8 \mu \mathrm{M}$ ) and $\mathrm{A} 549$ (with an $\mathrm{IC}_{50}$ value of $7.4 \mu \mathrm{M}$ ) cell lines and moderate activity against HepG2 cells, with an $\mathrm{IC}_{50}$ value of $15.5 \mu \mathrm{M},{ }^{[30]}$ miyabenol $\mathrm{C}(\mathbf{8 0})$ exerted an inhibitory effect on protein kinasec in a non-competitive inhibition mode. ${ }^{[70]}$ Miyabenol C (80) kobo-phenol A (82) and (+)- $\alpha$-viniferin (84) could significantly inhibit the growth of A549 cells, and the effects of these compounds on the activities of egg autokinase $\mathrm{C}$ and isozymes in two human lung cancer cell lines (CA549 and $\mathrm{HCl}-\mathrm{H} 446)$ were studied. The results $(80)$ showed they could inhibit the activity of PKc and decrease the content of PKc-a in the granule fraction, thus hindered the membrane translocation of A549 cells. ${ }^{\text {[71] }}$

\section{Antimalarial activity}

Longistylin A and C (3-4) showed a moderately high in vitro activity against the chloroquine-sensitive Plasmodium falciparum strain $3 \mathrm{D} 7,{ }^{[6]}$ machaeriol $\mathrm{B}(\mathbf{2 6})$ demonstrated in vitro antimalarial activity $\left(\mathrm{IC}_{50}=120 \mathrm{ng} / \mathrm{mL}\right)$ against Plasmodium falciparum W-2 clone. ${ }^{[18]}$

\section{Antimicrobial activity}

Cicerfuran (5) showed potent antifungal activity against spores of $F$. oxysporum f. sp. ciceri ${ }^{[8]}$ and chiricanine $A(17)$ was the only prenylated stilbene to demonstrate antifungal effects against Cladosporium cucumerinum. ${ }^{[16]}$ The preliminary antimicrobial activities of the crude extracts/fractions and the $\mathrm{IC}_{50}$ values of machaeriols $\mathrm{A}-\mathrm{B}(\mathbf{2 5 - 2 6 )}$ were determined by using a modified 96 -well microplate assay protocol. ${ }^{[18]}$ The antimicrobial activity of amorfrutins A-B (144-145) was limited to Gram-positive and acid-fast microorganisms and compounds (144-145) were essentially equipotent. ${ }^{[58]}$

\section{Hypoglycemic activity}

2'-O-Demthylbidwillol B (10), addisofuran A (11), addisofuran $B$ (12) inhibited PTP1B activity with $\mathrm{IC}_{50}$ values of $13.6 \pm 1.1,17.5 \pm 1.2$, and $15.7 \pm 1.6 \mu \mathrm{M}^{[11]}$

\section{Antioxidant activity}

Lespedezavigatol (16) showed strong oxygen radical
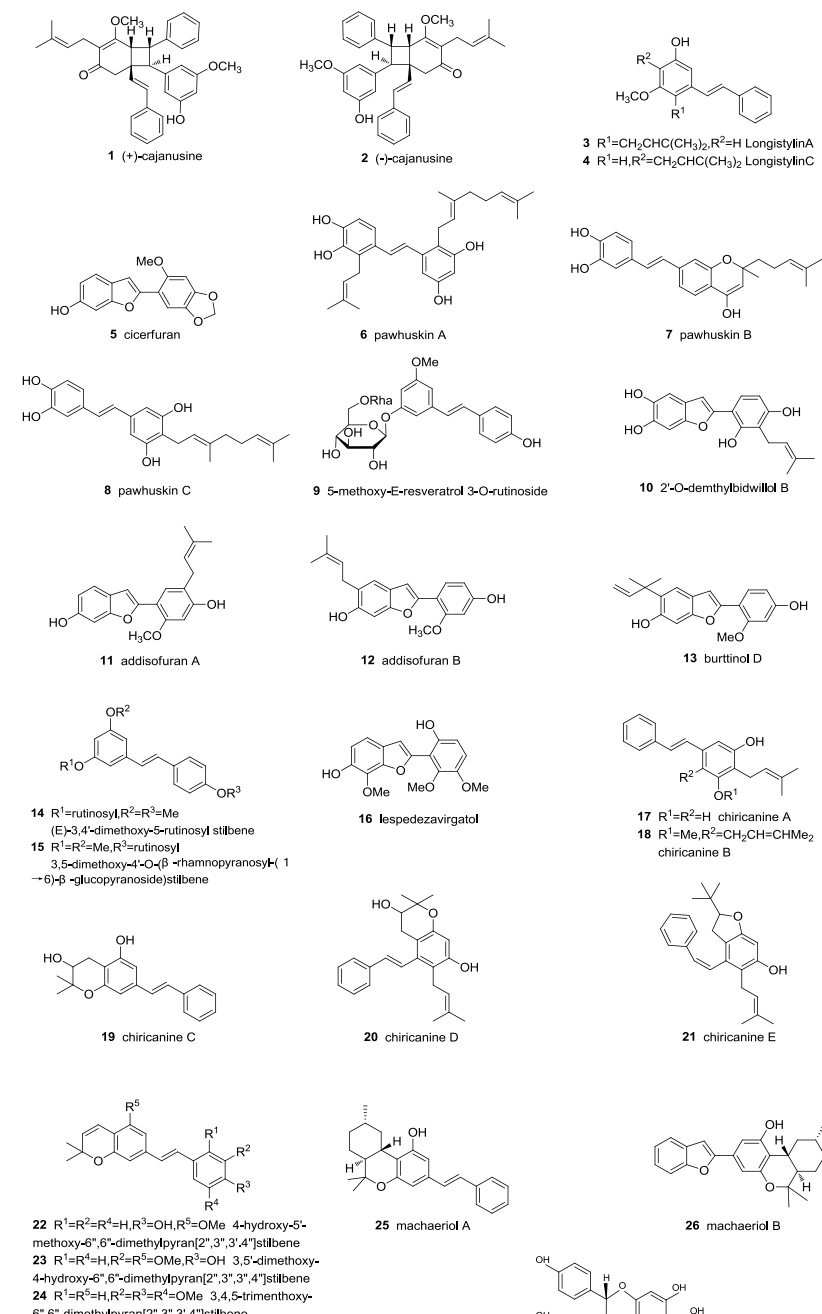

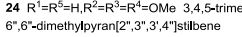
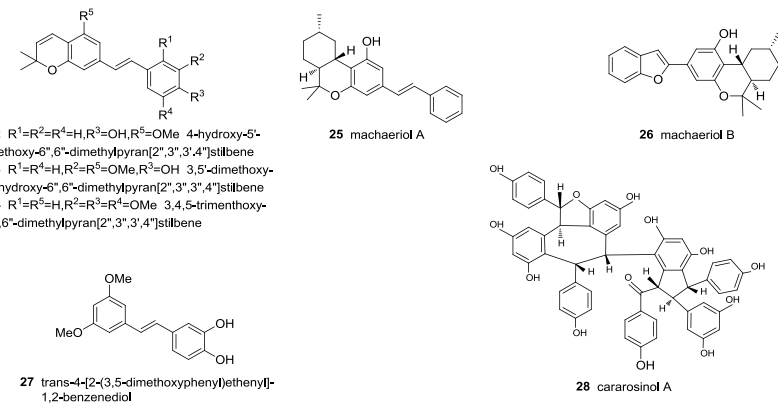

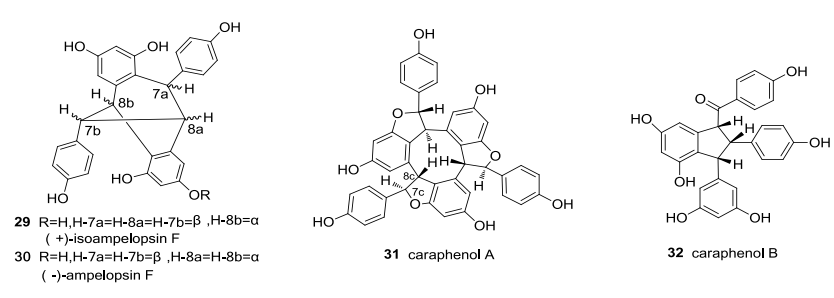

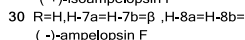
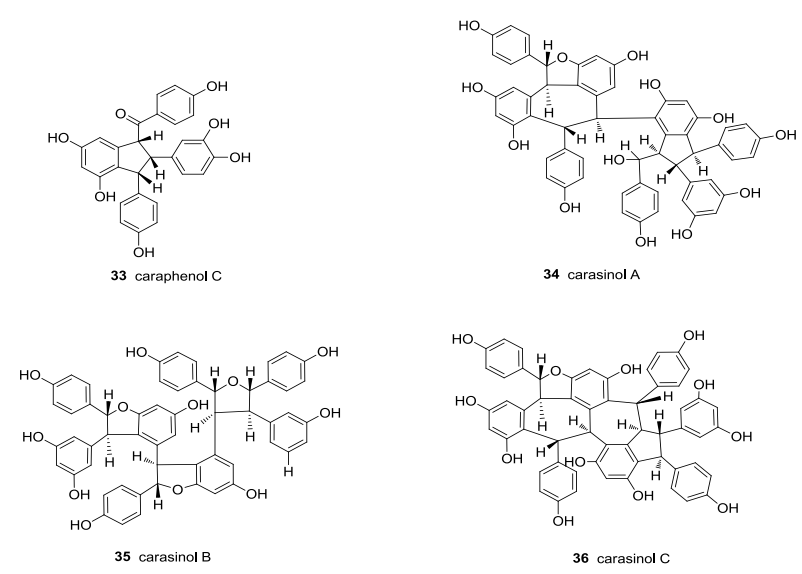

35 carasinol B

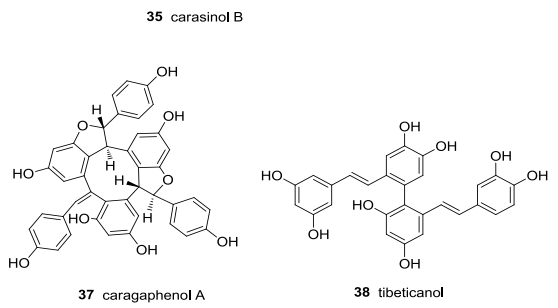$$
\text { (a) }
$$
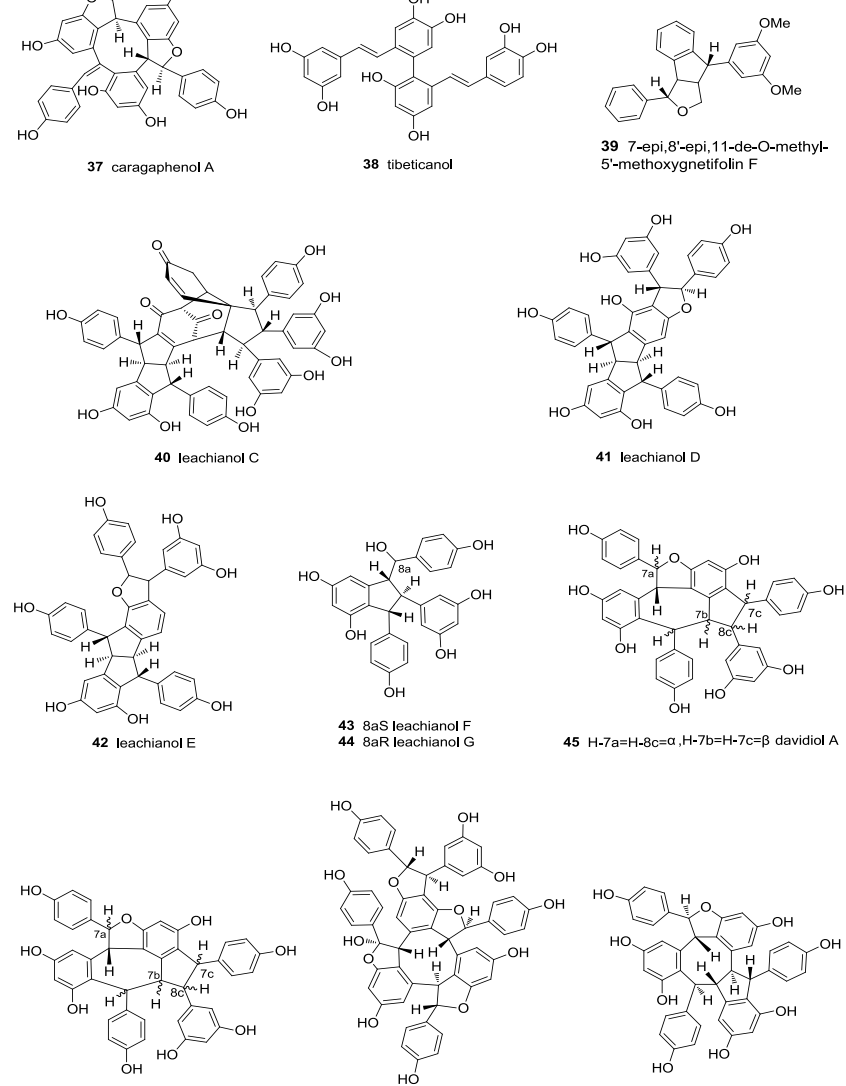

$45 \mathrm{H}-7 \mathrm{a}=\mathrm{H}-8 \mathrm{c}=\alpha, \mathrm{H}-7 \mathrm{~b}=\mathrm{H}-7 \mathrm{c}=\beta$ davidiol $\mathrm{A}$
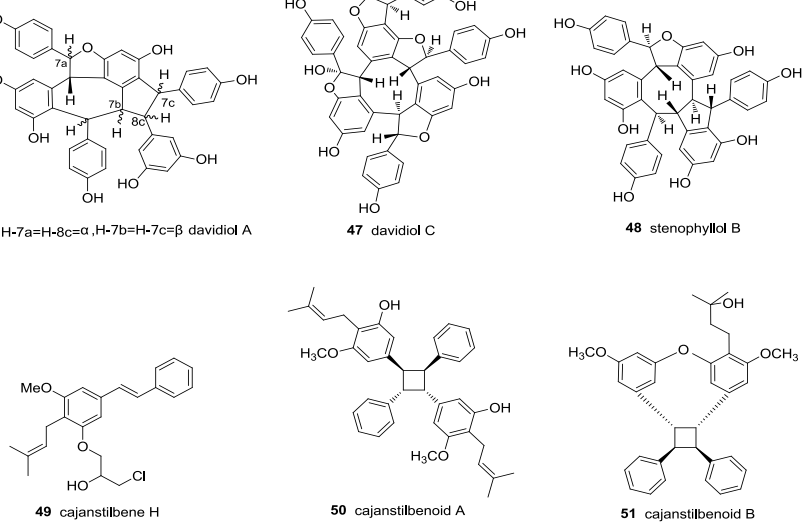
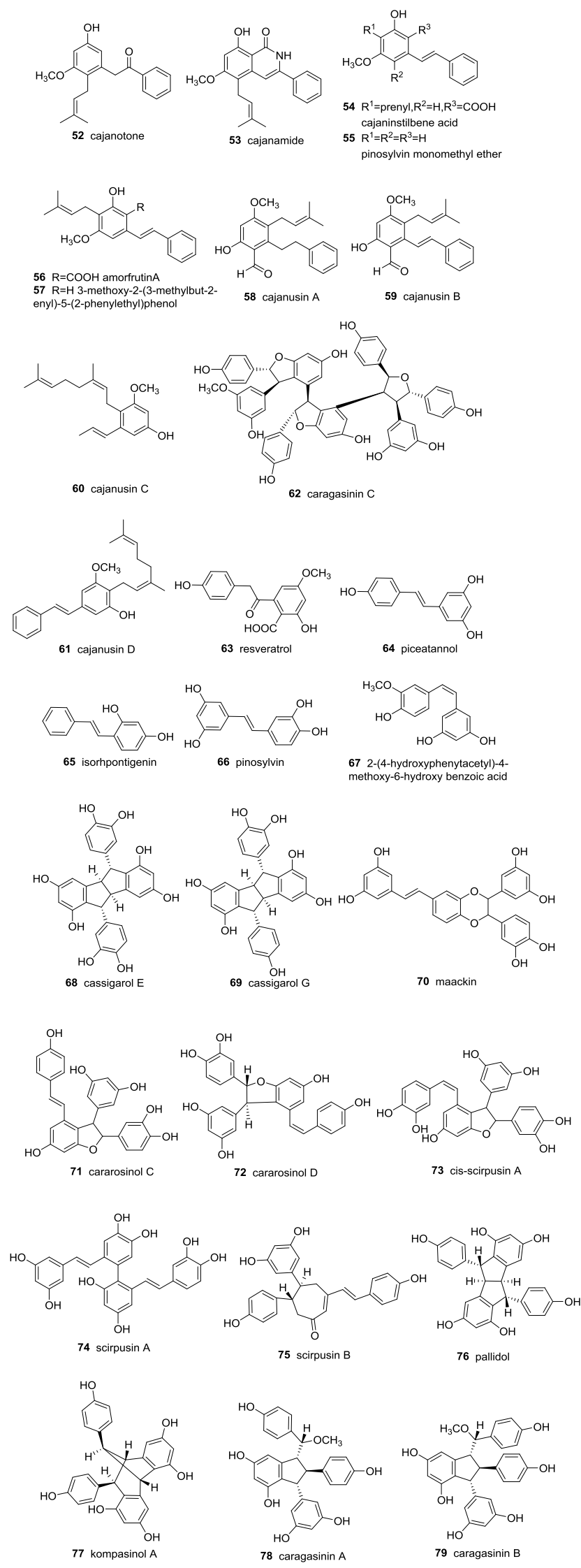

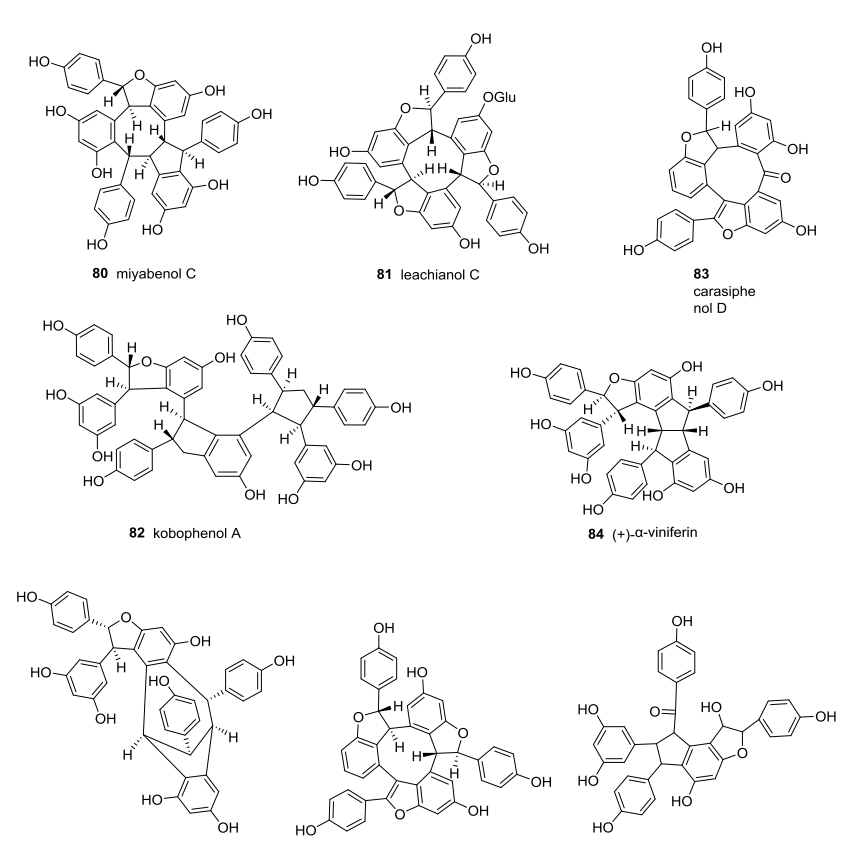

85 carasiphenol B

$87(+)$
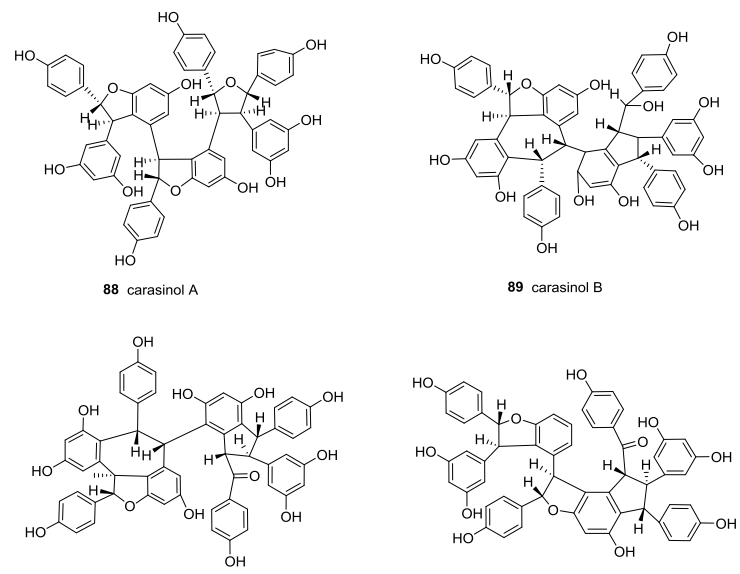

90 carasinol C

91 carasinol D
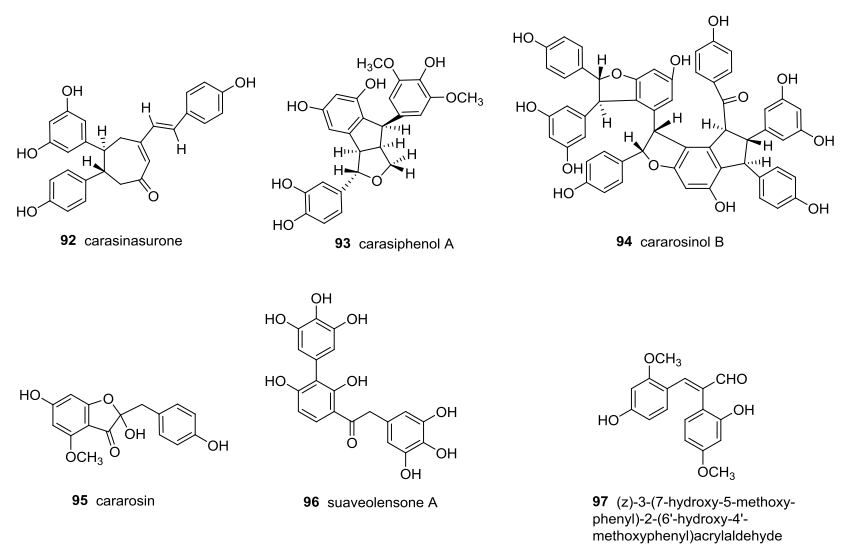

$98 \mathrm{R}=\mathrm{H}$ 3,5-dimethoxy-4-prenyl
stibene

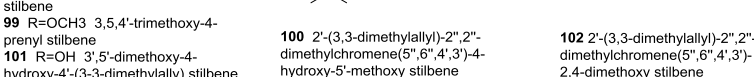

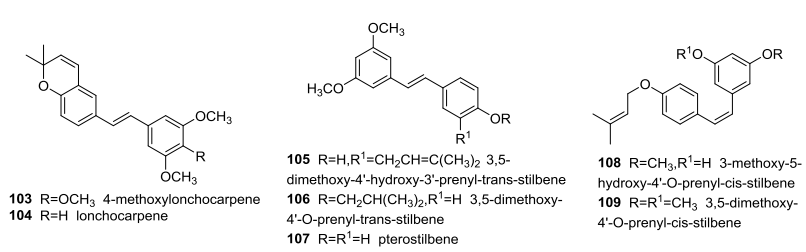

$\overbrace{\mathrm{OCH}_{3}}^{\mathrm{OH}}$

110 3-methoxy-5-hydroxy-4'-O-prenyl-
trans-stilibene

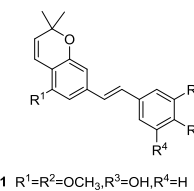

$111 \mathrm{R}^{1}=\mathrm{R}^{2}=\mathrm{OCH}_{3}, \mathrm{R}^{3}=\mathrm{OH}, \mathrm{R}^{4}=\mathrm{H} 3,5^{1}-$

dimethoxy-4-hydroxy-6",6"

$112 \mathrm{R}^{1}=\mathrm{H}, \mathrm{R}^{2}=\mathrm{R}^{3}=\mathrm{R}^{4}=\mathrm{OCH}_{3}, 3,4,5$

trimenthoxy-6" $66^{n-}$

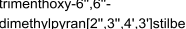

$113 \mathrm{R}^{1}=\mathrm{OCH} \mathrm{CH}_{3} \mathrm{R}^{2}=\mathrm{R}^{4}=\mathrm{H}, \mathrm{R}^{3}=\mathrm{OH}$ 4-hydrox $\mathrm{s}$

$5^{\prime}$-methoxy-6",6"-

dimethylpyran[2",3",3,4]"stibene

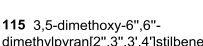

116 3-hydroxy-4-prenyl-5-methoxy-
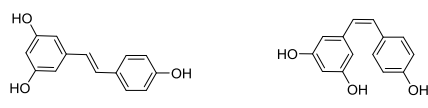

(1)

114 4-hydroxy-5"-methoxy-6",6"-
dimethylpyran[2",3",4,3]']tilbene

(<smiles>CCOc1cc(CC=CC2CCCC(O)C2)cc(OC(C)O)c1</smiles>

120 trans-piceid
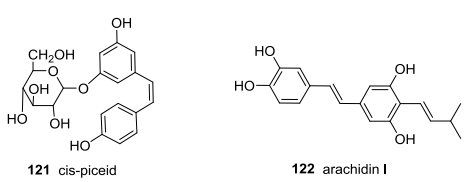

(1)

123 arachidin II

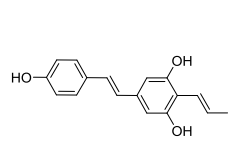

(125

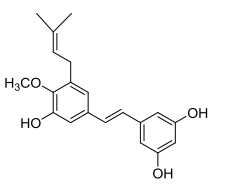

$126 \quad 3,5,53$ '-trihydroxy-4:-
methoxy-5'-'-isopentenylstilbene
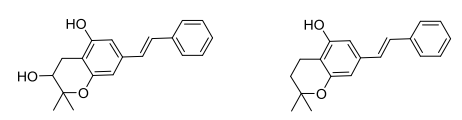

128 arahypin-13

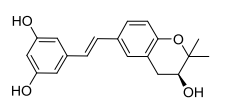

129 arahypin-14

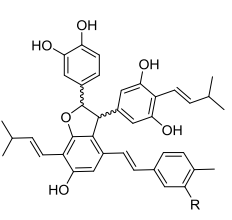

$131 \mathrm{R}=\mathrm{H}$ arahypin 6
$132 \mathrm{R}=\mathrm{OH}$ arahypin 7

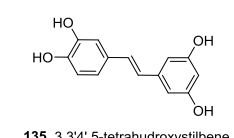

135 3,3'3',5-tetrahudroxystibene

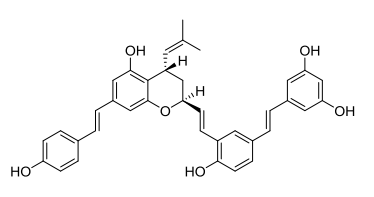

133 arahypin 11

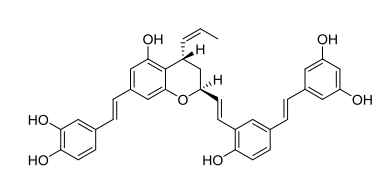

134 arahypin 12

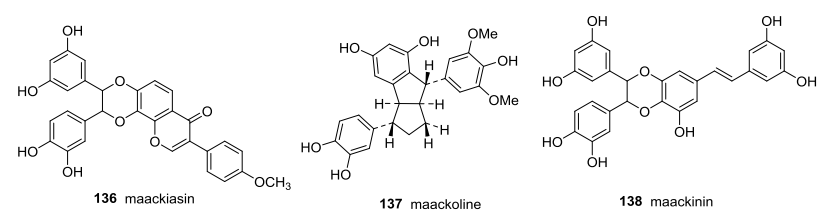




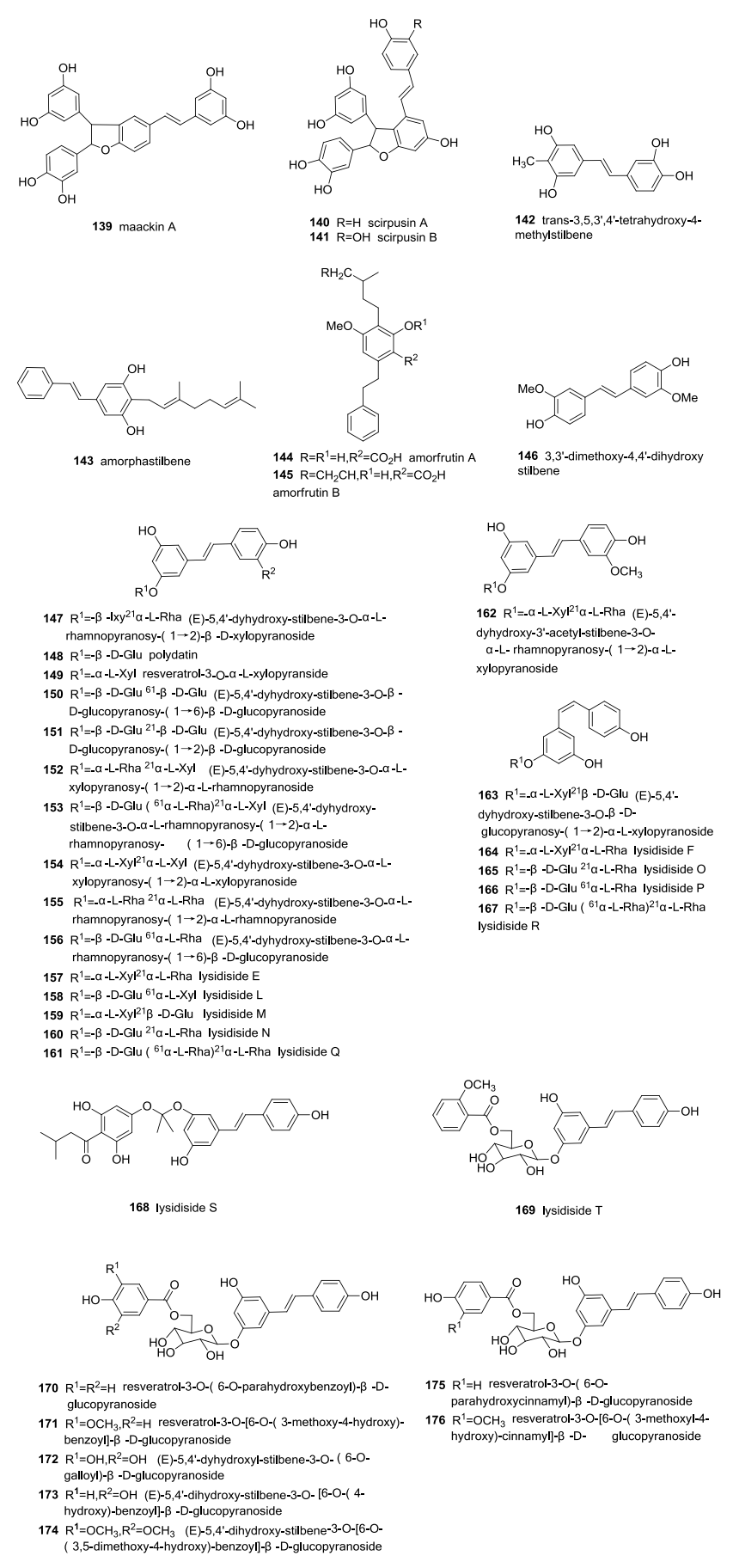

Figure 1 The structures of stilbenes from Leguminosae.

absorbance capacity and potent inhibition toward lipid peroxidation in both plasma and kidney homogenate of renal failure rats. ${ }^{[15]}$ Tibeticanol (38) showed the highest antioxidant activity since it possesses two catechol groups in a molecule and a well-conjugated structure. ${ }^{[24]}$ Caragasinin A (78), caraphenol B (32), caragasinin B (79) have good antioxidant effects $\left(I_{50}=34.70 \pm 1 \sim 98.10 \pm 2.30 \mu \mathrm{mol} / \mathrm{L}\right),{ }^{[39]} 3,3^{\prime}, 4^{\prime}, 5-$ tetrahydroxystilbene (135), maackiasin (136) had strong antioxidant activity. ${ }^{[55]}$

\section{Insect-resistant activity}

Chiricanines B-E (18-21) showed toxic properties against larvae of the yellow fever-transmitting mosquito Aedes aegypti. ${ }^{[16]}$

\section{Estrogenic activity}

It was found that (+)-isoampelopsin $F(29),(-)$-isoampelopsin $F(30)$, and caraphenols $A-C(31-33)$ had the effects of stimulating the proliferation (the reproduction rates of cultured osteoblasts were raised $11 \%-37 \%$ in different concentration $\left(10^{-10}-10^{-4} \mathrm{~g} / \mathrm{mL}\right)$ than that of the control group $(0 \mathrm{~g} / \mathrm{mL})$, enhancing the ALP activities and increasing the number of mineral nodes of cultured osteoblasts. MTT method was used to observe the activity of stimulating the growth of osteoblasts. ${ }^{[21]}$ Carasinol A (34) and carasinol C (36) had the effects of stimulating the proliferation of cultured osteoblasts, ${ }^{[22]}$ cajanstilbene $\mathrm{H}$ (49) distinctly promoted osteoblast differentiation in HMSC (human mesenchymal stem cell) in dose and time-dependent manners, ${ }^{[29]}$ leachianol C (81), kobophenol A (82), and compounds (88-91) could stimulate the proliferation of osteoblasts to a certain extent. ${ }^{[35]}$

\section{Anti-inflammatory and analgesic activity}

(+)- $\alpha$-Viniferin (84) can inhibit the release of free radicals in blood and inhibit prostaglandin $\mathrm{H} 2$ synthase $\left(\mathrm{IC}_{50}=7.00 \mu \mathrm{M}\right)$, which is about three times that of resveratrol. ${ }^{[72]}$

\section{Conclusions and Perspectives}

In recent years, researchers have conducted in-depth studies on the chemistry and biological activity of stilbene compounds and found some stilbene with strong activity, all of which have a strong ability to scavenge free radicals. The distribution of stilbene is limited, and it is only found in more than 30 plant families. Due to the diversity of oligomer structure, degree of polymerization and stereochemistry, the range of oligomer is very wide. This paper reviews hydroquinone and its anti-tumor, antibacterial, anti-inflammatory and antimalarial activities in 13 genera of Leguminosae. Stilbenes are rich sources of lead compounds in the search for new drugs. Resveratrol, a representative compound, has been tested in clinical trials as a drug for the treatment of Alzheimer's disease and tumors, andhas shown satisfactory therapeutic effects. However, most of the chemical constituents in the pharmacological analysis are still unclear and should attract the attention of phytochemists and pharma- cologists, some of which have potential for development.

\section{Acknowledgement}

This work was supported by the National Natural Science Foundation of China (Nos. 81860612, 81703793), the Social Development Supportive Program of Science \& Technology Department of Guizhou Province (No. [2018]2767), the Joint Fund by Science \& Technology Bureau of Guiyang and Guizhou Medical University (No. [2017]30-37).

\section{Conflict of Interest}

The authors declare no conflict of interest.

Copyright (c) 2019 Xinyu Lei, Qinru Zhou, Wenju Li, Guifang Qin, Xiangchun Shen, and Nenling Zhang. This article is an open access article distributed under the terms and conditions of the Creative Commons Attribution (CC BY) license (http://creativecommons.org/ licenses/by/4.0/). The use, distribution or reproduction in other forums is permitted, provided the original author(s) or licensor are credited and that the original publication in this journal is cited, in accordance with accepted academic practice. No use, distribution or reproduction is permitted which does not comply with these terms.

\section{References}

[1] Patel, S.; Panchal, H. K.; Bioinformatics information of Legumin- 
osae family in Gujarat State. Biotechnology 2014, 173, 22302732X.

[2] Zhu, X. Nomenclatural novelties and new synonyms of Leguminosae in China. Biodiv Sci. 2015, 23, 247-251.

[3] Zhao, Y. M.; Guo, Y.; Sang, J. N. Distribution and physiological activity of stilbene compounds. Sci. Technol. Chem. Ind. 2015, 23, 77-80.

[4] Sivaji, K.; Arulchakkaravarthi, A.; Selvakumar, S.; Ramasamy, P.; Sankar, S.; Varghese, B. Electron momentum distribution mapping of trans-stilbene single crystal by positron annihilation. Chem. Phys. Lett. 2005, 412.

[5] Li, X. L.; Zhao, B. X.; Huang, X. J.; Zhang, D. M.; Jiang, R. W.; Li, Y. J.; Jian, Y. Q.; Wang, Y.; Li, Y. L.; Ye, W. C. (+)- and $(-)$-cajanusine, a pair of new enantiomeric stilbene dimers with a new skeleton from the leaves of Cajanus cajan. Org. Lett. 2014, 16, 224-227.

[6] Dukereshun, G.; Jaroszewski, J. W.; Asomaning, W. A. Antiplasmodial Constituents of Cajanus cajan. Phytother. Res. 2004, 18, 128-130.

[7] Tao, S.; Xiaolin, W.; Hongxiang, L. Natural stilbenes: an overview. Nat. Prod. Rep. 2009, 26.

[8] Stevenson, P. C.; Veitch, N. C. A 2-arylbenzofuran from roots of cicer bijugum associated with fusarium wilt resistance. Phytochemistry 1998, 48, 947-951.

[9] Belofsky, G.; French, A. N.; Wallace, D. R.; Dodson, S. L. New geranyl stilbenes from dalea purpurea with in vitro opioid receptor affinity. J. Nat. Prod. 2004, 67, 26-30.

[10] Wanjala, C. C. W.; Majinda, R. R. T. A new stilbene glycoside from Elephantorrhiza goetzei. Fitoterapia 2001, 72, 649655.

[11] Na, M. K.; Hoang, D. M.; Njamen, D.; Mbafor, J. T.; Fomum, Z. T.; Thuong, P. T.; Ahna, J. S.; Ohd, W. K. Inhibitory effect of 2-arylbenzofurans from Erythrina addisoniae on protein tyrosine phosphatase-1B. Bioorg. Med. Chem. Lett. 2007, 17, 3868-3871.

[12] Yenesew, A.; Midiwo, J. O.; Guchu, S. M.; Heydenreich, M.; Peter, M. G. Three isoflav-3-enes and a 2-arylbenzofuran from the root bark of Erythrina burttii. Phytochemistry 2002, 59, 337-341.

[13] Nyemba, A. M.; Mpondo, T. N.; Kimbu S. F.; Connolly, J. D. Stilbene glycosides from guibourtia tessmannii. Phytochemistry 1995, 39, 895-898.

[14] Fuendjiep, V.; Wandji, J.; Tillequin, F.; Mulholland, D. K.; Budzikiewicz, H.; Fomum, Z. T.; Nyemba, A. M.; Koch, M. Chalconoid and stilbenoid glycosides from Guibourtia tessmanii. Phytochemistry 2002, 60, 803-806.

[15] Chen, Y.; Wei, X.; Xie, H.; Deng, H. Antioxidant 2-phenylbenzofurans and a coumestan from lespedeza wirgata. J. Nat. Prod. 2008, 71, 929 .

[16] loset, J. R.; Marston, A.; Gupta, M. P.; Hostettmann, K. Five new prenylated stilbenes from the root bark of lonchocarpus chiricanus. J. Nat. Prod. 2001, 64, 710-715.

[17] Fang, N.; Casida, J. E. New bioactive flavonoids and stilbenes in cube' resin insecticide. J. Nat. Prod. 1999, 62, 205.

[18] Muhammad, I.; Li, X. C.; Dunbar, D. C.; ElSohly, M. A.; Khan, I. A. Antimalarial (+)-trans-Hexahydrodibenzopyran Derivatives from Machaerium multiflorum. J. Nat. Prod. 2001, 64, 1322-1325.

[19] Ma, Z. J.; Li, X.; Li, N.; Wang, J. H. Stilbenes from Sphaerophysa salsula. Fitoterapia 2002, 73, 313-315.

[20] Yang, G. X.; Hu, C. Q. A New Stilbene Tetramer from Caragana rosea. Chin. Chem. Lett. 2003, 57,1048-1050.

[21] Luo, H. F.; Zhang, L. P.; Hu, C. Q. Five novel oligostilbenes from the roots of Caragana sinica. Tetrahedron 2001, 57, 4849-4854.

[22] Ma, D. Y.; Luo, H. F.; Hu, C. Q. Three stilbene tetramers from the roots of curaguna sinica. Chemistry 2004, 22, 207-211.

[23] Hongxia, L.; Wenhan, L.; Junshan, Y. Oligomeric stilbenes from the root of caragana stenophylla. Chem. Pharm. Bull. 2004, 52, 1339-1341.

[24] Xiang, T.; Uno, T.; Ogino, F.; Ai, C.; Duo, J.; Sankawa, U.
Antioxidant constituents of caragana tibetica. Chem. Pharm. Bull. 2005, 53, 1204-1206.

[25] Kulesh, N. I.; Denisenko, V. A.; Maksimov, O. B. Stilbenolignan from maackia amurensis. Phytochemistry 1995, 40, 1001-1003.

[26] Ohyama, M.; Tanaka, T.; linuma, M. Five resveratrol oligomers from roots of sophora leachiana. Phytochemistry 1995, 38, 733-740.

[27] Tanaka, T.; Ito, T.; linuma, M.; Ohyama, M.; Ichise, M.; Tateishi, Y. Stilbene oligomers in roots of Sophora davidii. Phytochemistry 2000, 53, 1009-1014.

[28] Ohyama, M.; Tanaka, T.; linuma, M. Phenolic compounds isolated from the roots of sophora stenophylla. Chem. Pharm. Bull. 1998, $46,663-668$

[29] Cai, J. Z.; Tang, R.; Ye, G. F.; Qu, S. X.; Zhang, N. L.; Hu, Y. J.; Shen, X. L. A halogen-containing stilbene derivative from the leaves of cajanus cajan that induces osteogenic differentiation of human mesenchymal stem cells. Molecules 2015, 20, 1083910847.

[30] Zhang, N. L.; Zhu, Y. H.; Huang, R. M.; Fu, M. Q.; Su, Z. W.; Cai, J. Z.; Hu, Y. J.; Qiu, S. X. Two new stilbenoids from cajanus cajan. $Z$. Naturforsch. (B) 2012, 67, 1314-1318.

[31] Zhang, N. L.; Shen, X. C.; Jiang, X. F.; Cai, J. Z.; Shen, X. L.; Hu, Y. J.; Qiu, S. X. J. Nat. Med.-Tokyo 2017, 72, 304-309.

[32] Wu, G. Y.; Zhang, X.; Guo, X. Y.; Huo, L. Q.; Liu, H. X.; Shen, X. L.; Qiu, S. X.; Hu, Y. J.; Tan, H. B. Prenylated stilbenes and flavonoids from the leaves of Cajanus cajan. Chin. J. Nat. Med. 2019, 17, 381-386.

[33] Jeong, W.; Ahn, E. K.; Oh, J. S.; Hong, S. S. Caragasinin C: a new oligostilbene from the roots of Caragana sinica. J. Asian Nat. Prod. Res. 2017, 19, 1-5.

[34] Pan, L.;Jia, X. Y.;Zheng, C. J.; Jia, Y. .;Suti,L. Y. b.; L i ,N.; Li, X. Z.; $\mathrm{Jia}, \mathrm{X}$. G. Research Progress of stilbene compounds in Caragana. J. Xinjiang Med. Univ. 2016, 39, 1070- 1074.

[35] Dayou, M. Ph.D. Dissertation, Fudan University, Shanghai, China, 2003.

[36] Na, S. Ph.D. Dissertation, Fudan University, Shanghai, China, 2006.

[37] Niu, X.; Li, Y.; Li, W.; Hu, H.; Yao, H.; Li, H.; Mu, Q. The anti-inflammatory effects of Caragana tangutica ethyl acetate extract. J. Ethnopharmacol. 2014, 152, 99-105.

[38] Shuguang, W. Ph.D. Dissertation, Fudan University, Shanghai, China, 2004.

[39] Jin, Q.; Han, X. H.; Hong, S. S.; Lee, C.; Choe, S.; Lee, D.; Kim, Y.; Hong, J. T.; Lee, M. K.; Hwang, B. Y. Antioxidative oligostilbenes from Caragana sinica. Bioorg. Med. Chem. Lett. 2012, 22, 973976.

[40] Yang, G. X. Studies on the Anti-HIV Chemical constituents of the aboveground part of Caragana Caragana. J. Pharm. 2007, 42, 179-182.

[41] Yang, C. J. Ph.D. Dissertation, Tianjin University, Tianjin, China, 2008.

[42] Ngoupayo, J.; Tabopda, T. K.; Ali, M. S.; Ngadjui, M. S.; Lacailledubois, M. A. Antioxidant stilbenoid and flavanonol from stem of Erythrophleum suaveolens (Guill. \& Perr.). Magn. Reson. Chem. 2015, 53, 612-615.

[43] Nguyen, P. H.; Na, M.; Dao, T. T.; Ndinteh, D. T.; Mbafor, J. T.; Park, J.; Cheong, H.; Oh, W. K. New stilbenoid with inhibitory activity on viral neuraminidases from Erythrina addisoniae. Bioorg. Med. Chem. Lett. 2010, 20, 6430-6434.

[44] Fang, N.; Casida, J. E. Cube' Resin Insecticide: Identification and biological activity of 29 rotenoid constituents. J. Agric. Food. Chem. 1999, 47, 2130-2136.

[45] Lima, N. M.; Andrade, J. I. A.; Lima, K. C. S.; Santos, F. N. d. Chemical profile and biological activities of Deguelia duckeana A.M.G. Azevedo (Fabaceae). Nat. Prod. Res. 2013, 27, 425-432.

[46] MagalhaÄes, A. F.; Tozzi, A. M. G. A.; MagalhaÄes, E. G.; Moraes, 
V. r. R. d. S. Prenylated avonoids from Deguelia hatschbachii and their systematic signi cance in Deguelia. Phytochemistry 2001, 57, 77-89.

[47] Gomes, C. M.; Gottlieb, O. R.; Bettolo, G. B. M.; Delle Monache, F.; Polhill, R. M. Systematic significance of flavonoids in derris and Ionchocarpu. Biochem. Sysr. Ecol. 1981, 9, 129-147.

[48] Lobo, L. T.; da Silva, G. A.; de Freitas, M. C. C.; Souza, A. P. S.; da Silva, M. N.; Arruda, A. C.; Guilhon, G. M. S. P.; Santos, L. S.; Santos, A. S.; Arruda, M. S. P. Stilbenes from Deguelia rufescens var. urucu (Ducke) A. M. G. Azevedo Leaves: Effects on Seed Germination and Plant Growth. J. Braz. Chem. Soc. 2010, 21, 1838-1844.

[49] Fuchino, H.; Kiuchi, F.; Yamanaka, A.; Obu, A.; Wada, H.; Mori-Yasumoto, K.; Kawahara, N.; Flores, D.; Palacios, O.; Sekita, S.; Satakeg, M. New leishmanicidal stilbenes from a peruvian folk medicine, Ionchocarpus nicou. Chem. Pharm. Bull. 2013, 61, 979982

[50] Fang, J.; Casida, J. E. New bioactive flavonoids and stilbenes in cube' resin insecticide. J. Nat. Prod. 1999, 62, 206-210.

[51] Marques, E. d. J.; Serafim, J. C. d. R. B.; Lemes, B. B.; Carvalho, M. F. A.; Pereira, M. d. G.; Neta, L. C. d. S. Occurrence and distribution of polyphenolics in species of Deguelia (Leguminosae). Microb. Biochem. Technol. 2015, 7, 327-333.

[52] Ersam, T.; Fatmawati, F.; Fauzia, D. N. New prenylated stilbenes and antioxidant activities of Cajanus cajan (L.) Millsp. (Pigeon pea). Indones. J. Chem. 2016, 16, 151-155.

[53] Sales, J. M.; Resurreccion, A. V. A. Resveratrol in Peanuts. Crit. Rev. Food. Sci. 2014, 54, 724-770.

[54] Shen, J.; Zhou, Q.; Li, P.; Wang, Z.; Liu, S.; He, C.; Zhang, C.; Xiao, $P$. Update on phytochemistry and pharmacology of naturally occurring resveratrol oligomers. Molecules 2017, 22, 2050.

[55] Li, J. F.; Cui, Z.; Zang, F. L. Research progress on chemical constituents and pharmacological action of Maackia hupehensis. $J$. Shenyang Pharm. Univ. 2006, 23, 542-545.

[56] Li, Y.; Zhang, D. M.; Yu, S. S. A new stilbene from cercis chinensis bunge. J. Integr. Plant Biol. 2005, 47, 1021-1024.

[57] Kemals, M.; Khalil, K. W.; Rao, N. G. S.; Woolsey, N. F. Isolation and identification of a cannabinoid-like compound from amorpha species. J. Nat. Prod. 1979, 42, 463-468.

[58] Mitscher, L. A.; Park, Y. H.; Alshamma, A.; Hudson, P. B.; Haas, T. Amorfrutin $a$ and $b$, bibenzyl antimicrobial agents from amorpha fruticosa. Phytochemistry 1981, 20, 781-785.

[59] Shihui, S. Ph.D. Dissertation, Beijing Union Medical University, Beijing, China, 2007.
[60] Song, N. N.; Wang, Y. R.; Huang, X. F. Research progress on chemical constituents and pharmacological activities of Lysidice. Nat. Prod. Res. Dev. 2016, 28, 791-780.

[61] Song, G. Ph.D. Dissertation, Beijing Union Medical University, Beijing, China, 2004.

[62] Song, G. Resveratrol/phloroglucinol glycosides from the roots of Lysidice rhodostegia. Planta Med. 2007, 2.

[63] Hu, Y. C. Ph.D. Dissertation, Beijing Union Medical University, Beijing, China, 2008.

[64] Hu, Y. C.; Ma, S. G.; Li, J. B.; Yu, S. S.; Qu, J.; Liu, J.; Du, D. Targeted isolation and structure elucidation of stilbene glycosides from the bark of Lysidice brevicalyx Wei guided by biological and chemical screening. J. Nat. Prod. 2008, 11, 1800-1805.

[65] Hu, Y. C.; Qu, J.; Liu, Y. Y.; Yu, S. S.; Li, J. B.; Zhang, J. L.; Du, D. Structural characterization of trace stilbene glycosides in Lysidice brevicalyx Wei using liquid chromatography/diode-array detection/ electrospray ionization tandem mass spectrometry. J. Chromatogr. B 2010, 878, 1 .

[66] Jing, Q. Structural characterization of constituents with molecular diversity in fractions from Lysidice brevicalyx by liquid chromatography/diode-array detection/electrospray ionization tandem mass spectrometry and liquid chromatography/nuclear magnetic resonance. Rapid Commun. Mass Spectrom. 2008, 6, 755-765.

[67] Wu, X. F. Ph.D. Dissertation, Beijing Union Medical University, Beijing, China, 2009.

[68] Hu, Y. C.; Ma, S. G.; Yu, S. S.; Wu, X. F.; Li, Y. Phenolic glycosides isolated from the bark of Lysidice brevicalyx Wei. $J$. Asian Nat.Prod. Res. 2010, 6, 516-521.

[69] Jing, Q. Ph.D. Dissertation, Beijing Union Medical University, Beijing, China, 2007.

[70] Kulanthaivel, P.; Janzen WPBallas, L. M.; Jiang, J. B.; Hu, C. Q.; Darges, J. W. Naturally occurring protein kinase C inhibitors; II. Isolation of oligomeric stilbenes from Caragana sinica. Planta Med. 1995, 61, 41-44.

[71] Zhi, S.; Guang, X. Inhibitory effect of stilbenes on the growth of lung cancer cell line. J. Shanghai Med. Univ. 1998, 5, 7-10.

[72] Lee, S. H.; Shin, N. H.; Kang, S. H.; Park, J. S.; Chung, S. R.; Min, K. R.; Kim, Y. Alpha-viniferin: a prostaglandin $\mathrm{H} 2$ synthase inhibitor from root of Carex humilis. Planta Med. 1998, 64, 204-207.

Received February 5, 2020 Accepted February 15, 2020 